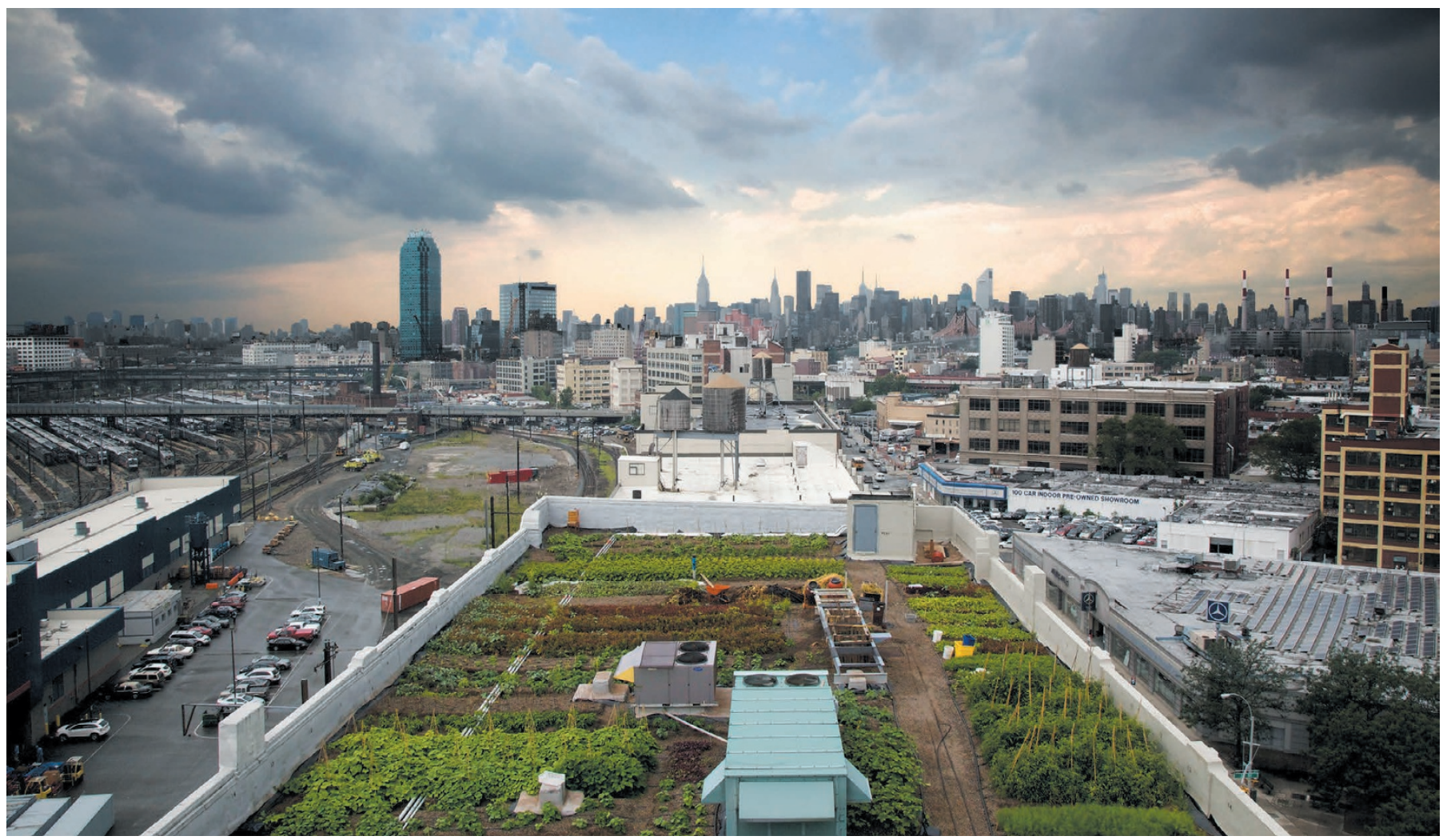

Brooklyn Grange, a 1-hectare organic farm that spans two rooftops in New York City.

\title{
AGRICULTURE
}

\section{Sowing the city}

\section{As holiday feasts begin, Laura Lawson surveys the fruitful history of urban farming.}

$\mathrm{T}$ he floating gardens of Aztec Mexico; the Versailles kitchen garden that supplied the table of Louis XIV of France; hydroponic vertical farming in Japan. Throughout history, agriculture has been integrated into cities in various forms, moulded by environmental conditions, design intent and technological and agronomic innovation. Today, an explosion in studies on urban agriculture is broadening perspectives. It's illuminating the view from Africa and Latin America in Luc Mougeot's 2005 Agropolis (Earthscan), the varied historical contexts in Dorothée Imbert's edited Food and the City (Harvard Univ. Press, 2015) and the design propositions in André Viljoen's 2005 CPULs: Continuous Productive Urban Landscapes (Routledge). These books not only normalize urban farming, but also address how it can be adapted to tackle food security.

According to the 1996 report Urban Agriculture by the United Nations Development Programme, an estimated 800 million urban dwellers worldwide grow food and raise livestock. However, many people still ask whether urban agriculture can grow enough food to be useful. The assumption is that farming is best as a rural practice, with extensive land and trained farmers to maximize productivity. Many others are increasingly concerned about the impacts of the agro-food system on health and the environment, and look to the different possibilities of urban agriculture - addressing nutrition, economic development, community activism and environmental awareness.

Urban farming is, in fact, rarely bracketed with the agro-food system, but it is crucial to initiatives that address food access and affordability. It also gives farmers the flexibility to choose crops on the basis of genetic diversity or cultural preferences - such as 'heritage' vegetables or varieties valued by recent immigrants. It is not a variation on rural agriculture, but a distinct practice.

\section{GROWING TOGETHER}

Farming has been part of the structure of cities for millennia, with farmers supplying urban markets and repurposing waste such as manure (see 'Capitals of cultivation'). In
The Economy of Cities (Random House, 1969), urban theorist Jane Jacobs (A. Williams Nature 537, 614-615; 2016) argued that agriculture did not precede early cities: instead, cities inspired agriculture through their centrality to trade and capacity for innovation. Archaeological evidence from France to Iran - of canal and irrigation systems, terracing and walled enclosures reveals the large investment often needed to sustain urban productivity.

Colonization plans such as Spain's Law of the Indies - which held for 400 years in the Americas and the Philippines - placed agriculture close to cities such as Santo Domingo to ease access to crops and animals, provide waste management and protect food supply. In 1683, William Penn, founder of Pennsylvania, planned Philadelphia as a "green country town" where productive orchards and gardens would ensure fresh air and reduce the risk of fire. Later, Ebenezer Howard's British 'garden cities' incorporated allotments and farms in 'green belts', starting with Letchworth at the turn of the twentieth century. In 1928, the German landscape architect Leberecht Migge 
proposed to integrate allotment gardens into public housing developments around an expanding Frankfurt. And US architect Frank Lloyd Wright planned a decentralized settlement (never realized) called Broadacre City, in which each family was allotted almost half a hectare for food production.

Whether informal or planned, agriculture has had to adapt to urban expansion. In some cases, this has led to intensive, innovative cultivation to increase yields and support higher-value goods. From the twelfth to the nineteenth centuries, farmers in the Marais district of Paris transformed swampland into productive gardens and manipulated microclimates to grow peas, artichokes, figs and apricots. They planted densely in raised beds nourished with (and kept warm by) horse manure, and used cold frames and cloche coverings to extend the growing season, as well as trellis supports to encourage fruit yields. Yet even with innovation and intensification, rising land costs and improved transport often led farmers in Paris and elsewhere to relocate to otherwise unbuildable sites, or out into the urban periphery.

City farming has also been a way to relieve poverty. The nineteenth and twentieth centuries saw English urban allotments, French jardins familiaux and jardins ouvriers, German kleingärten and, in US cities such as New York, vacant-lot cultivation associations and relief gardens that provided land and training as both direct aid and social reform. Gardening was about food, but also about tradition, culture, education and morale, for instance harnessing the know-how of immigrants. These programmes laid the way for domestic food production in Australia, Europe and North America during the two world wars, when hundreds of thousands of civilians grew their own food so that commercial crops could serve the war effort. Second $>$

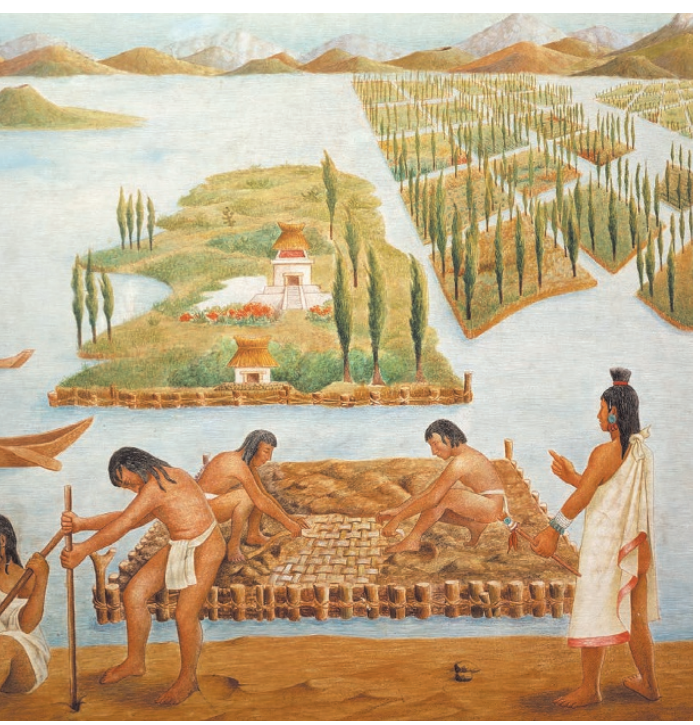

Aztecs farming on an artificial islands called a chinampa in Tenochtitlan.

\section{Books in brief}

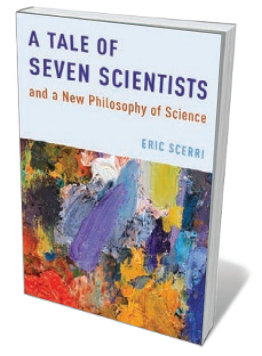

A Tale of Seven Scientists and a New Philosophy of Science

Eric Scerri OXFORD UNIVERSITY PRESS (2016)

Is scientific discovery all about starry intellects and eureka moments? Philosopher of science Eric Scerri asserts otherwise in this thoughtful treatise on research as evolution, not revolution collective, piecemeal endeavour rather than heroic act. Scerri spotlights seven 'unknowns' who, pivoting around the work of Niels Bohr and Dmitri Mendeleev, helped to unravel atomic structure. So physicist John Nicholson's concept of the quantization of angular momentum informed Bohr's quantum theory of the atom, and the amateur Anton van den Broek pioneered the idea of atomic number.

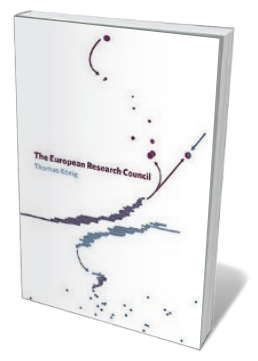

The European Research Council

Thomas König POLITY (2016)

A beacon of science policy and research funding, the European Research Council (ERC) is about to celebrate its first decade. In this first comprehensive history, Thomas König — former scientific adviser to ERC president Helga Nowotny — offers a multifaceted perspective. Behind the ERC's success in maintaining excellence in 'frontier' research, he reveals, a welter of complex negotiations have played out in the politicized current of its framework funding programme, Horizon 2020. A story of big scientific personalities and struggles for autonomy and accountability in the charged space between policy and science.

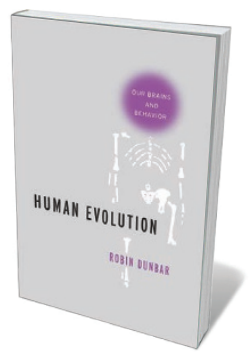

\section{Human Evolution: Our Brains and Behavior}

Robin Dunbar OXFORD UNIVERSITY PRESS (2016)

"Stones and bones" dominate the human-evolution story, notes evolutionary anthropologist Robin Dunbar. In this exemplary study, he plunges instead into the "murky, unseen social world" during the 6 million to 8 million years since the hominin lineage diverged from that of other African great apes. Drawing on research from the British Academy's From Lucy to Language project (H. Gintis Nature 509, 284-285; 2014), Dunbar traces shifts in biology, genetics and neurology over that key period. It's a compelling journey into human nature, from the roots of our sociality to the rise of storytelling.

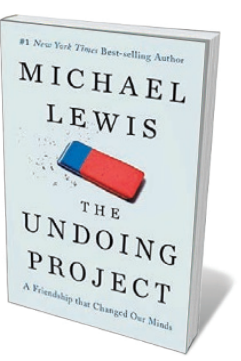

\section{The Undoing Project: A Friendship That Changed Our Minds} Michael Lewis W. W. NORTON (2016)

Soon after Michael Lewis published Moneyball (W. W. Norton, 2003), his best-seller on the metrics of sports recruitment, he found that the concepts were not original. Psychologists Daniel Kahneman and Amos Tversky got there decades before, codifying the systematic bias in our decision-making when faced with uncertainty. Lewis tells the story of this rare scientific collaboration and its impact on behavioural economics with novelistic brio, tracing the dual evolution of Kahneman and Tversky's intense relationship and their research all the way to a denouement of human sorrow and Nobel glory.

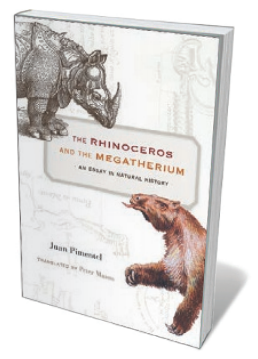

The Rhinoceros and the Megatherium: An Essay in Natural History Juan Pimentel; transl. Peter Mason HARVARD UnIVERSITY PRESS (2017) In this subtly discursive study, historian of science Juan Pimentel looks at two animals that profoundly marked science, yet were "imagined without being seen". One was the rhinoceros famously hypothesized by Albrecht Dürer in a 1515 woodcut. The other was a Megatherium fossil discovered in 1788 that, rendered in an engraving, allowed comparative anatomist Georges Cuvier to identify it as a giant sloth. Pimentel's inspired pairing limns how image and imagination shape our understanding of nature. Barbara Kiser 


\section{CAPITALS OF CULTIVATION}

Agriculture has been part of the

urban infrastructure since cities first began.

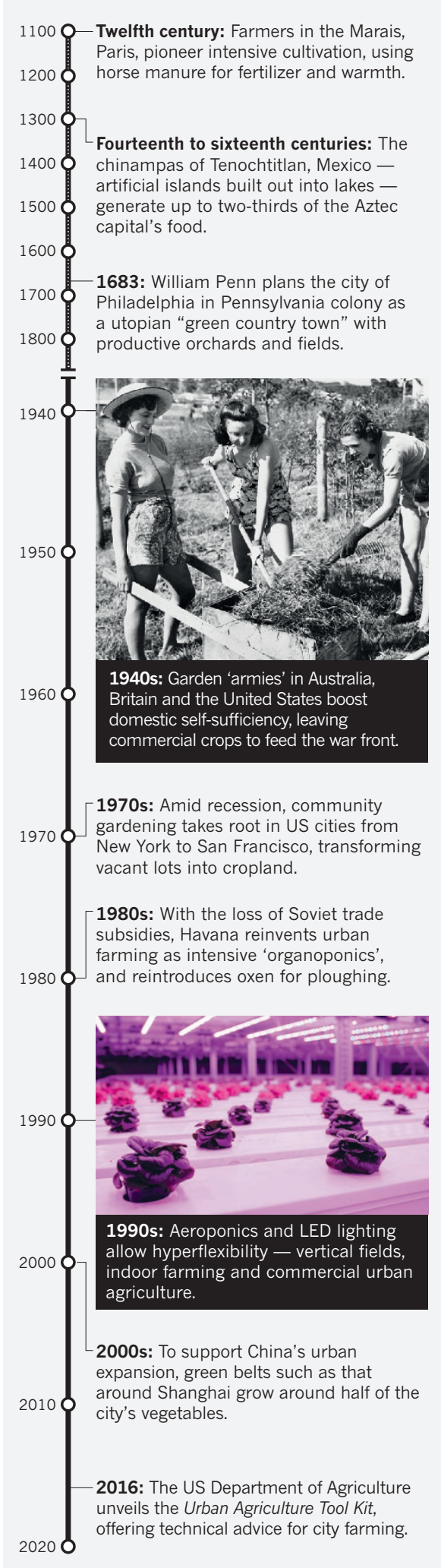

- World War 'victory gardens' in Britain, for instance, saw everything from swathes of London's Hyde Park to railway embankments do duty as cropland. Community-garden activism in the 1970s and 1980s built on the legacy of such programmes but focused on community empowerment. Movers and shakers emerged, such as Liz Christy, first director of the Council on the Environment of New York City's Open Space Greening Program. And the movement led to neighbourhood gardens and city-wide advocacy organizations including Boston Urban Gardeners in Massachusetts.

\section{A MOVEABLE FEAST}

Over time, unique tensions have emerged around urban agriculture. Its mess, noise and perceived unruliness can vie with city authorities' urge towards order and cleanliness. Animal husbandry has been a flashpoint. Millions of urban dwellers in the developing world raise everything from chickens to camels, but this form of farming was an early casualty in the West. Philadelphia's free-ranging pigs, for instance, succumbed to early-twentieth-century legislation and the closure of urban livestock markets.

The dirty reputation of farming persists in some Western cities. With a globalized food system capable of propelling asparagus from Peru into British supermarkets, food planning and policy in Western cities tend to focus on trucking and warehousing, leaving officials prone to viewing localized production as a regressive, temporary use of urban space. Some urban-farm designers attempt to neaten up the image with colourful geometric plant displays next to street cafes and on rooftops. But they risk promoting style over substance: such plans rarely acknowledge the realities of cultivation, such as seasonality and the need for fallow beds.

Thus urban agriculture has become a moveable feast - opportunistic or mandated, marginal or essential. Since the 1990s, initiatives by bodies such as the Food and Agriculture Organization of the United Nations have encouraged policies, pilot projects and microlending to support farming for food security in many poorer African and Asian cities. And in socio-economically deprived postindustrial regions such as Germany's Ruhr valley and the Rust Belt in the US northeast and midwest, urban agriculture is seen as generating economic activity and enabling access to better food. Growing Power, an organization founded by former basketball star Will Allen in Milwaukee, Wisconsin, provides training in closed-loop 'aquaponics' among other urban production practices across the United States (see go.nature.com/2gzhj4p).

Elsewhere, Chinese megacities such as Shanghai are supporting agricultural green belts to retain local access to fresh vegetables. Cuba, long separated from global markets, produces roughly $60 \%$ of its vegetables in towns and cities, with remarkable success based on traditional practices such as reintroducing oxen for ploughing. In 2011, San Francisco, California, passed an urban-agriculture ordinance that made farming an allowable use of land and source of saleable food. Agriculture is also included in the sustainability plans of cities such as Seattle, Washington, to reduce its carbon footprint and green the infrastructure. And housing developments including Serenbe outside Atlanta, Georgia, are embracing community-supported agriculture, farmers' markets and farm-to-table cuisine as a 'lifestyle choice'.

In tandem with the push for sustainable business and circular economies (B. Kiser et al. Nature 531, 443-446; 2016), high-tech options are emerging. Vertical urban farms, hydroponic greenhouses and aeroponic factories offer intensive production to offset high real-estate costs. AeroFarms in Newark, New Jersey, perfected its aeroponic salad-

\section{"Urban. agriculture will be there when new challenges} arise. growing process at a local school in 2011 and now anticipates harvests of more than 4 million kilograms per year. But these capital-intensive projects demand business savvy, and critics argue that their presence can lead to older models such as community gardens being undervalued.

Agricultural urbanism is entering a new phase as a framework to address community cohesion and food access. From Shanghai to Detroit, advocates are mapping the urbanagriculture landscape - highlighting the existence of vacant lots and 'food desert' neighbourhoods ripe for transformation. Often, this enables farmers to network, discuss shared concerns and advocate. A model is New York City's Five Borough Farm, a project of the Design Trust for Public Space. Here, site documentation, metrics development and proposals for supportive policies and practices are managed collectively.

And the future? Urban agriculture offers promise for coping with climate change. Eschewing reliance on vulnerable transport connections, experimenting with seasonality and crop selection, and strengthening community ties will help both mitigation and adaptation. Urban agriculture will be there when new challenges arise, and will continue to evolve as it responds to key issues that shape our cities.

Laura Lawson is dean of agriculture and urban programmes at Rutgers University in New Brunswick, New Jersey. Her books include City Bountiful and Greening Cities, Growing Communities (co-authored with Jeffrey Hou and Julie Johnson). e-mail:ljlawson@sebs.rutgers.edu 